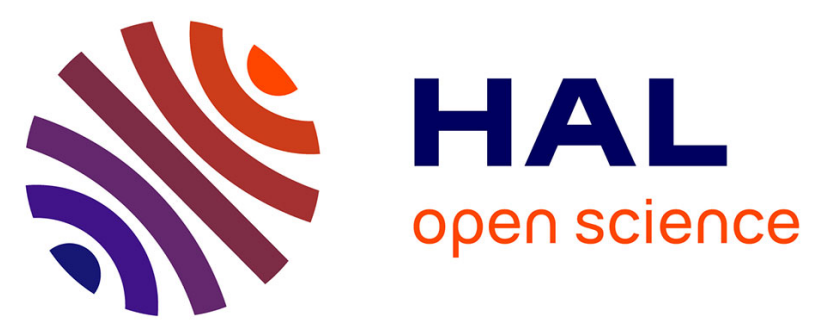

\title{
Measurements of mid-stratospheric formaldehyde from the Odin/SMR instrument
}

\author{
P. Ricaud, D. Alexandre, Brice Barret, E. Le Flochmoen, Erwan Motte, \\ Gwenaël Berthet, Franck Lefèvre, D. Murtagh
}

\section{- To cite this version:}

P. Ricaud, D. Alexandre, Brice Barret, E. Le Flochmoen, Erwan Motte, et al.. Measurements of midstratospheric formaldehyde from the Odin/SMR instrument. Journal of Quantitative Spectroscopy and Radiative Transfer, 2007, 107 (1), pp.91-104. 10.1016/j.jqsrt.2007.01.058 . hal-00138038

\section{HAL Id: hal-00138038 \\ https://hal.science/hal-00138038}

Submitted on 8 Jul 2021

HAL is a multi-disciplinary open access archive for the deposit and dissemination of scientific research documents, whether they are published or not. The documents may come from teaching and research institutions in France or abroad, or from public or private research centers.
L'archive ouverte pluridisciplinaire HAL, est destinée au dépôt et à la diffusion de documents scientifiques de niveau recherche, publiés ou non, émanant des établissements d'enseignement et de recherche français ou étrangers, des laboratoires publics ou privés.

\section{(c)(1)}

Distributed under a Creative Commons Attribution| 4.0 International License 


\title{
Measurements of mid-stratospheric formaldehyde from the Odin/SMR instrument
}

\author{
P. Ricaud ${ }^{\mathrm{a}, *}$, D. Alexandre ${ }^{\mathrm{a}}$, B. Barret ${ }^{\mathrm{a}}$, E. Le Flochmoën ${ }^{\mathrm{a}}$, E. Motte ${ }^{\mathrm{a}}$, \\ G. Berthet ${ }^{\mathrm{b}}$, F. Lefèvre ${ }^{\mathrm{c}}$, D. Murtagh ${ }^{\mathrm{d}}$ \\ ${ }^{a}$ Laboratoire d'Aérologie, CNRS/Université de Toulouse III, 14, Avenue Edouard Belin, 31400, Toulouse, France \\ ${ }^{\mathrm{b}}$ Laboratoire de Physique et de Chimie de l'Environnement, CNRS, 3 A, Avenue de la Recherche Scientifique, 45071 Orléans Cedex 2 , France \\ ${ }^{\mathrm{c}}$ Service d'Aéronomie, CNRS, Université Pierre et Marie Curie, 4 Place Jussieu, 75252 Paris Cedex 05, France \\ d Department of Radio and Space Science, Chalmers University of Technology, 41296 Göteborg, Sweden
}

\begin{abstract}
Measurements of mid-stratospheric formaldehyde $\left(\mathrm{H}_{2} \mathrm{CO}\right)$ have been obtained from the limb-viewing sub-millimeter radiometer (SMR) instrument aboard the Odin satellite. The analysis is based upon the only weak $\left(8_{08} \rightarrow 7_{07}\right)$ rotational transition line of $\mathrm{H}_{2} \mathrm{CO}$ that can be measured by Odin/SMR at $576.7083150 \mathrm{GHz}$ in the band dedicated to the measurement of carbon monoxide (CO). The signal-to-noise ratio is increased by averaging about 1000 spectra within 2-km width vertical layers in the stratosphere over periods from 1 to 7 days and within 3 latitude bands: Southern Hemisphere $\left(90^{\circ} \mathrm{S}-45^{\circ} \mathrm{S}\right)$, tropics $\left(30^{\circ} \mathrm{S}-30^{\circ} \mathrm{N}\right)$, and Northern Hemisphere $\left(45^{\circ} \mathrm{N}-90^{\circ} \mathrm{N}\right)$. The faint $\mathrm{H}_{2} \mathrm{CO}$ line can then be retrieved using the standard scientific ground-segment developed for the Odin/SMR measurements. The mid-stratospheric $\mathrm{H}_{2} \mathrm{CO}$ shows maxima in the tropics for every period considered (January 2006, February 2005, March 2005, and September 2005). The spring-time extra-tropical mid-stratospheric $\mathrm{H}_{2} \mathrm{CO}$ is more intense than the fall-time extra-tropical amounts. The simulations from the three-dimensional chemical-transport model Reprobus satisfactorily show these general features.
\end{abstract}

Keywords: Radiative transfer; Spectroscopy; Inversion; Formaldehyde; Remote sensing; Satellite; Stratosphere

\section{Introduction}

Remote sensing of the chemical composition of the Earth's atmosphere using passive microwave techniques has been intensively used since the beginning of the 1990s. Ground-based (e.g. [1]), balloon-borne (e.g. [2]), airborne (e.g. [3]) and satellite-based (e.g. [4]) instruments have indeed monitored a great number of molecules (ozone $\left(\mathrm{O}_{3}\right)$, chlorine monoxide $(\mathrm{ClO})$, water vapor $\left(\mathrm{H}_{2} \mathrm{O}\right)$, nitric acid $\left(\mathrm{HNO}_{3}\right)$, nitrous oxide $\left(\mathrm{N}_{2} \mathrm{O}\right)$, etc.). These data have provided valuable information to understand the evolution of the atmosphere, in particular the $\mathrm{O}_{3}$ layer, and its impact on climate change, and conversely, how climate change impacts upon the chemical

\footnotetext{
*Corresponding author. Tel.: + 33561332723 ; fax: + 33561332790 .

E-mail address: philippe.ricaud@aero.obs-mip.fr (P. Ricaud).
} 
composition of the atmosphere. More recently, by the use of very sensitive receivers either cooled or uncooled, both the millimeter and the sub-millimeter domains have become accessible to heterodyne technology. The possibility of detecting weak microwave lines in the Earth's atmosphere has widened the spectrum of measurable molecules to include isotopologues (e.g. $\mathrm{O}_{3}, \mathrm{H}_{2} \mathrm{O}$, etc.), weakly abundant species (e.g. methyl cyanide $\left(\mathrm{CH}_{3} \mathrm{CN}\right)$ [5], etc.) and vibrationally excited weakly populated states (e.g. $\mathrm{O}_{3}, \mathrm{HNO}_{3}$, etc.).

The limb-viewing Odin satellite launched in February 2001 contains a sub-millimeter radiometer (SMR) tuned to the frequency domains $486.1-503.9$ and $541.0-580.4 \mathrm{GHz}$ [6]. In its basic modes, it offers the possibility to measure target species like $\mathrm{O}_{3}, \mathrm{ClO}, \mathrm{N}_{2} \mathrm{O}, \mathrm{HNO}_{3}, \mathrm{H}_{2} \mathrm{O}$, and carbon monoxide (CO), and also some isotopologues of $\mathrm{O}_{3}$ and $\mathrm{H}_{2} \mathrm{O}$. Given the great quantity of spectra recorded so far, a statistical analysis based upon the average of thousands of measured spectra in order to reduce the random radiometric noise and thus increase the signal-to-noise ratio can characterize very weak line species in the sub-millimeter domain. Indeed, heavy isotopologue of water $\left(\mathrm{HD}^{18} \mathrm{O}\right)$, methanol $\left(\mathrm{CH}_{3} \mathrm{OH}\right)$ and vibrationally excited $\mathrm{N}_{2} \mathrm{O}$ have already been detected in the 501-GHz Odin/SMR band by averaging more than 400,000 spectra [7]. We apply the same methodology for detecting the only weak $\left(8_{08} \rightarrow 7_{07}\right)$ rotational transition line of formaldehyde $\left(\mathrm{H}_{2} \mathrm{CO}\right)$ that can be measured by Odin/SMR at $576.7083150 \mathrm{GHz}$, in the band originally dedicated to the measurement of the strong $\mathrm{CO}$ rotational transition $(5 \rightarrow 4)$ line at $576.2679305 \mathrm{GHz}$ together with the strong $\mathrm{O}_{3}$ rotational transition line $\left(10_{28} \rightarrow 9_{19}\right)$ at $576.5148750 \mathrm{GHz}$. In addition, we use the Odin/SMR scientific ground-segment developed for the standard operational mode in order to estimate the vertical distribution of $\mathrm{H}_{2} \mathrm{CO}$ in the middle stratosphere.

Measurements of $\mathrm{H}_{2} \mathrm{CO}$ are available mainly in the troposphere. They are in the form of integrated column or vertically resolved profiles. Different techniques and platforms are used: space-borne sensors in the UV-VIS with the Global Ozone Monitoring Experiment (GOME) [8], ship borne [9] and ground-based [10] Fourier transform infrared spectrometers, airborne and balloon-borne sensors using tunable diode laser absorption spectroscopy [11], aqueous collection and enzyme-fluorescence detection [12]. Since there are no measurements of mid-stratospheric $\mathrm{H}_{2} \mathrm{CO}$ in the literature to validate our retrievals except a stratospheric column amount [13], we finally compare the Odin/SMR measurements with the output from the threedimensional chemical-transport model Reprobus [14].

The main sources of tropospheric formaldehyde $\left(\mathrm{H}_{2} \mathrm{CO}\right.$ or $\left.\mathrm{CH}_{2} \mathrm{O}\right)$ are the surface emission of pollutants from anthropogenic activity (industrial exhaust, cars, etc.), and from biomass burning. The main source of stratospheric $\mathrm{H}_{2} \mathrm{CO}$ is linked to the oxidation of methane $\left(\mathrm{CH}_{4}\right)$ by $\mathrm{OH}$ and $\mathrm{O}\left({ }^{1} \mathrm{D}\right)$ that produces different organic compounds $\left(\mathrm{CH}_{3}, \mathrm{CH}_{3} \mathrm{O}_{2}, \mathrm{CH}_{3} \mathrm{OOH}, \mathrm{CH}_{3} \mathrm{NO}_{2}, \mathrm{CH}_{3} \mathrm{O}, \mathrm{CH}_{3} \mathrm{OH}\right.$, and $\left.\mathrm{CH}_{3}(\mathrm{OH}) \mathrm{O}_{2}\right)$ that finally, chemically or by photolysis, produce $\mathrm{H}_{2} \mathrm{CO}$ (see Fig. 1). The main sinks of $\mathrm{H}_{2} \mathrm{CO}$ are the photolysis and reactions with $\mathrm{OH}, \mathrm{HO}_{2}, \mathrm{NO}_{3}, \mathrm{Cl}$ and $\mathrm{Br}$. Note that $\mathrm{H}_{2} \mathrm{CO}$ is an excellent tracer in the troposphere for

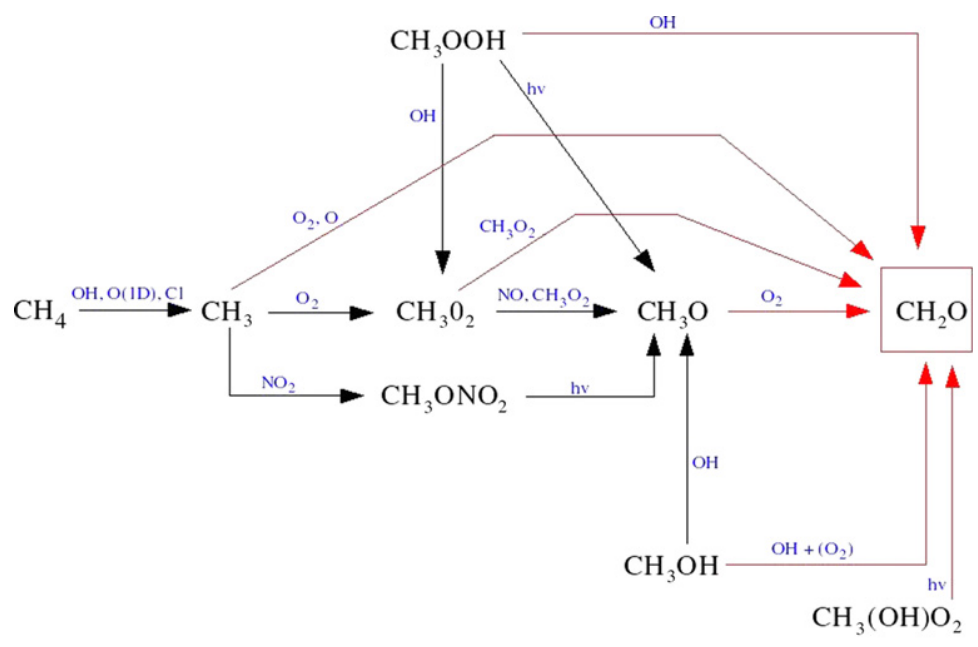

Fig. 1. Schematic representation of the stratospheric sources of formaldehyde. 
diagnosing pollution [15], while in the stratosphere, $\mathrm{H}_{2} \mathrm{CO}$ indirectly acts on the $\mathrm{O}_{3}$ budget since its photolysis produces $\mathrm{CO}$, an $\mathrm{O}_{3}$ precursor when oxidized by $\mathrm{OH}$.

The datasets used in the present manuscript are presented in Section 2, namely the Odin/SMR measurements and the Reprobus model. Due to a failure in the Odin/SMR phase-lock loop (PLL), measured spectra need to be calibrated in frequency prior to the averaging process. The method is also explained in Section 2. The estimation of $\mathrm{H}_{2} \mathrm{CO}$ vertical profiles from averaged measured spectra is detailed in Section 3. The measured $\mathrm{H}_{2} \mathrm{CO}$ vertical profiles obtained during several months and latitude bands are shown and discussed in Section 4, and finally compared with the outputs from the Reprobus model.

\section{ODIN dataset}

\subsection{Measurements}

The Odin mini-satellite is a Swedish-led project funded jointly by Sweden, Canada, France, and Finland $[6,16]$. It was placed into a 600-km Sun-synchronous, terminator orbit (i.e. crossing equator at 18:00 local time) by a START-1 rocket on 20 February 2001, and is still operational. Observation time is equally shared between astronomy and aeronomy. Odin includes two instruments. A UV-visible and infrared instrument, the optical spectrograph and infrared imager system (OSIRIS), that is capable of detecting $\mathrm{O}_{3}, \mathrm{NO}_{2}$, and aerosol in the scattered sunlight in the wavelength range $280-800 \mathrm{~nm}$ and the related oxygen airglow emission at $1.27 \mu \mathrm{m}$ [17]. The second instrument is the SMR [18] that can measure $\mathrm{O}_{3}, \mathrm{ClO}, \mathrm{N}_{2} \mathrm{O}, \mathrm{HNO}_{3}, \mathrm{H}_{2} \mathrm{O}$ and isotopologues, and $\mathrm{CO}$ in the frequency domains $486.1-503.9$ and $541.0-580.4 \mathrm{GHz}$. The great majority of these molecules have been validated (see e.g. [19-21] for CO). Data processing for both instruments uses temperature and pressure fields analyzed by the European Centre for Medium-range Weather Forecast (ECMWF).

In the aeronomy mode, several frequency bands have been optimally selected in order to study the abovementioned target species [16]. The only $\mathrm{H}_{2} \mathrm{CO}$ transition that can be detected in the pre-selected frequency bands is the weak $\left(8_{08} \rightarrow 7_{07}\right)$ rotational transition line at $576.7083150 \mathrm{GHz}$. This line is measured in the band dedicated to the observation of the strong $\mathrm{CO}$ rotational transition $(J=5 \rightarrow 4)$ line at $576.2679305 \mathrm{GHz}$ together with the strong $\mathrm{O}_{3}$ rotational transition line $\left(10_{28} \rightarrow 9_{19}\right)$ at $576.5148750 \mathrm{GHz}$ [22]. Different observation modes, namely "odd hydrogen," "stratospheric" and "water isotopologues," enable the detection of the $\mathrm{CO}$ and $\mathrm{O}_{3}$ lines, and consequently the $\mathrm{H}_{2} \mathrm{CO}$ line, from either strato-mesospheric scans from 7 to $110 \mathrm{~km}$ or mesospheric scans from 55 to $110 \mathrm{~km}$. The full auto-correlator bandwidth of $800 \mathrm{MHz}$ is used in this band, with an effective resolution of $2 \mathrm{MHz}$. The altitude step between consecutive spectra can vary from 1.5 to $3 \mathrm{~km}$ in the stratosphere and is set to $5.5 \mathrm{~km}$ in the mesosphere. This corresponds to integration times varying from 1 to $3 \mathrm{~s}$ in the stratosphere, while it is $4 \mathrm{~s}$ in the mesosphere.

\subsection{Spectrum correction and average}

As already presented in [19], the local oscillator frequency of the 572-GHz radiometer is no longer stable due to a failure in the PLL. This means that the measured frequency of the $800-\mathrm{MHz}$ total band is randomly shifted compared to the expected frequency. Typical values for the years 2005 and 2006 are ranging from -180 to $+30 \mathrm{MHz}$. The two $800-\mathrm{MHz}$ auto-correlators are in fact constituted of 8 sub-bands of $100-\mathrm{MHz}$ bandwidth. The two correlators had a failure in one of the sub-bands. The unavailable sub-band has been pushed towards the edge of the $800-\mathrm{MHz}$ total bandwidth, reducing the effective total bandwidth to $700 \mathrm{MHz}$. As a consequence of these two independent failures (the PLL and the 100-MHz sub-band), for some periods, the $\mathrm{CO}$ line or the $\mathrm{O}_{3}$ line, and consequently the $\mathrm{H}_{2} \mathrm{CO}$ weak line, cannot be observed even if the radiometer has been tuned to the $\mathrm{CO}$ band.

Nevertheless, in order to analyze the information contained in the CO band, an original method has been developed and slightly improved compared to the one explained in [19]. All the spectra measured during one scan are frequency calibrated by comparing the observed and calculated center frequencies of the $\mathrm{CO}$ line for tangent heights above $20-25 \mathrm{~km}$. The variation of the frequency shift within one scan is very weak, less than $\pm 1 \mathrm{MHz}$, i.e. within the spectral resolution of the auto-correlator. Below $20-25 \mathrm{~km}$, it is essentially impossible 
to calibrate in frequency the measured spectra since the $\mathrm{CO}$ line is absorbed in the strong $\mathrm{O}_{3}$ line wings. We then assume that the variation of the frequency shift along a scan is constant, to within $1 \mathrm{MHz}$, and we use this value to calibrate all the measured spectra belonging to one particular scan.

As an example, Fig. 2 shows spectra averaged within 2-km width vertical layers over the entire Earth (from $90^{\circ} \mathrm{S}$ to $90^{\circ} \mathrm{N}$ ) in January 2006 . This corresponds to 7 days of measurements and a number of $\sim 5000$ spectra averaged within each vertical layer. The $\mathrm{CO}$ and $\mathrm{O}_{3}$ lines are clearly detected and stabilized in frequency at 576.268 and $576.515 \mathrm{GHz}$, respectively. The $\mathrm{H}_{2} \mathrm{CO}$ weak line is highlighted by a vertical dotted line but is not visible using this large vertical scale. Note the dip in the measured brightness temperatures at frequencies greater than $576.9 \mathrm{GHz}$ corresponding to the presence of the unavailable $100-\mathrm{MHz}$ sub-band. For the same period, Fig. 3 shows a zoom around the transition frequency of the $\mathrm{H}_{2} \mathrm{CO}$ line at $576.708 \mathrm{GHz}$ for vertical layers between 30 and $62 \mathrm{~km}$. The $\mathrm{H}_{2} \mathrm{CO}$ line (vertical dotted line) is now clearly visible, well detached above the random noise. Other very faint lines are also detected. Over the total bandwidth of the CO band, Fig. 4 highlights the presence of transition lines from several atmospheric species: $\mathrm{ClO}$, various isotopologues of $\mathrm{O}_{3}$, vibrationally excited $\mathrm{O}_{3}$, etc.

Fig. 5a-d shows for different altitude layers, namely 38, 40, 42 and $44 \mathrm{~km}$, respectively the evolution of the $\mathrm{H}_{2} \mathrm{CO}$ spectra when averaged within different latitude bands: mid-to-high Southern Hemisphere latitudes $\left(\mathrm{SH}: 90^{\circ} \mathrm{S}-45^{\circ} \mathrm{S}\right)$, tropics $\left(30^{\circ} \mathrm{S}-30^{\circ} \mathrm{N}\right)$, mid-to-high Northern Hemisphere latitudes $\left(\mathrm{NH}: 45^{\circ} \mathrm{N}-90^{\circ} \mathrm{N}\right)$, and global $\left(90^{\circ} \mathrm{S}-90^{\circ} \mathrm{N}\right)$. The spectra correspond to an average over the January 2006

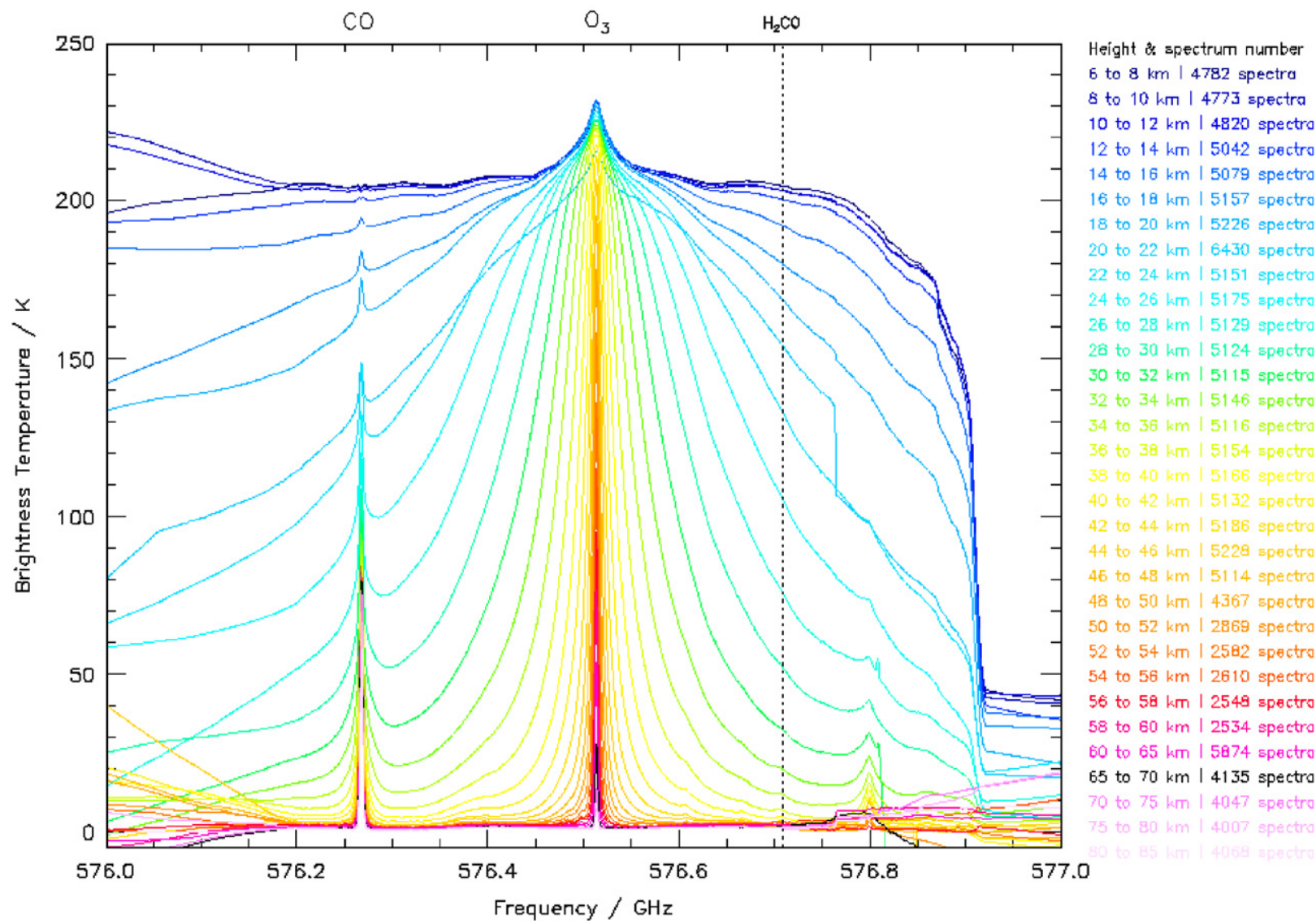

Fig. 2. Spectra representative of the band containing the $\mathrm{CO}$ and $\mathrm{O}_{3}$ transitions at 576.2679305 and $576.5148750 \mathrm{GHz}$, respectively, globally averaged from $90^{\circ} \mathrm{S}$ to $90^{\circ} \mathrm{N}$ over 7 days from 13 to 31 January 2006 within 2-km width vertical layers in the stratosphere and 5$\mathrm{km}$ width vertical layers in the mesosphere. The vertical dotted line shows the weak $\left(8_{08} \rightarrow 7_{07}\right)$ rotational transition frequency of the $\mathrm{H}_{2} \mathrm{CO}$ line at $576.7083150 \mathrm{GHz}$. 


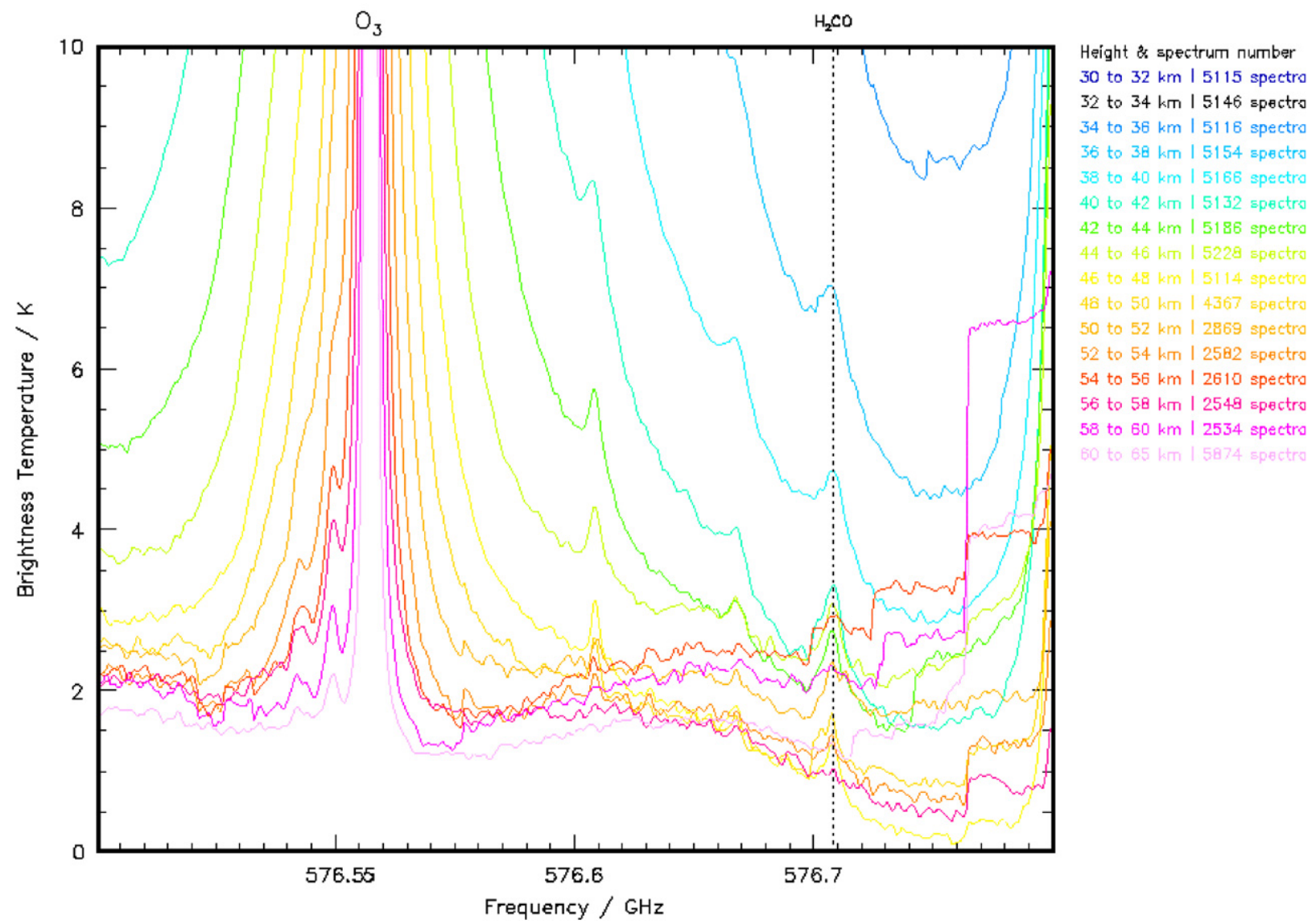

Fig. 3. Same as Fig. 2, but focussing around the $\mathrm{H}_{2} \mathrm{CO}$ line at $576.7083150 \mathrm{GHz}$ (vertical dotted line).

period. The maximum line intensity is about $1 \mathrm{~K}$ and the tropical line appears to be more intense than the other lines whatever the layer considered in the mid-stratosphere. Considering the retrieval as a linear problem, this already suggests that the amount of mid-stratospheric $\mathrm{H}_{2} \mathrm{CO}$ is higher in the tropics than at high latitudes.

In order to perform retrievals of the measured $\mathrm{H}_{2} \mathrm{CO}$ spectra, all the measurements obtained so far by the Odin/SMR instrument tuned to the CO band have been (1) frequency calibrated using the abovementioned method, and (2) averaged within vertical layers of $2-\mathrm{km}$ width from 0 to $60 \mathrm{~km}$, and of $5-\mathrm{km}$ width from 60 to $110 \mathrm{~km}$. The latter point ensures that the set of averaged spectra from 0 to $110 \mathrm{~km}$ is consistent with the vertical resolution of a single scan in a "strato-mesospheric" mode. As an example, the number of spectra averaged within a $2-\mathrm{km}$ stratospheric layer during the January 2006 period is $\sim 1000$ in the $\mathrm{NH}$ and $\mathrm{SH}$ bands, and $\sim 1800$ in the tropics. Given that the thermal noise for 1-s integration time is typically of $3 \mathrm{~K}$, this reduces the averaged random noise down to $0.1 \mathrm{~K}$, well below the measured 1-K amplitude of the $\mathrm{H}_{2} \mathrm{CO}$ line.

New level 1B files (containing information relative to the radiometers and calibrated and averaged spectra) are created that can be directly analyzed using the scientific data-processing segment maintained and updated at the Laboratoire d'Aérologie (France), the so-called Chaîne de Traitement Scientifique Odin (CTSO) Version V225. This version of the scientific segment is presented in [21], and enables the retrieval of $\mathrm{CO}$ and $\mathrm{O}_{3}$ vertical profiles in the $576-\mathrm{GHz}$ band. Once frequency calibrated, all the measured spectra are stored into $8231-\mathrm{MHz}$ channels from 576.038 to $576.862 \mathrm{GHz}$. The integration time associated to each averaged spectrum is simply the sum of the integration times of all the spectra taken into account. 


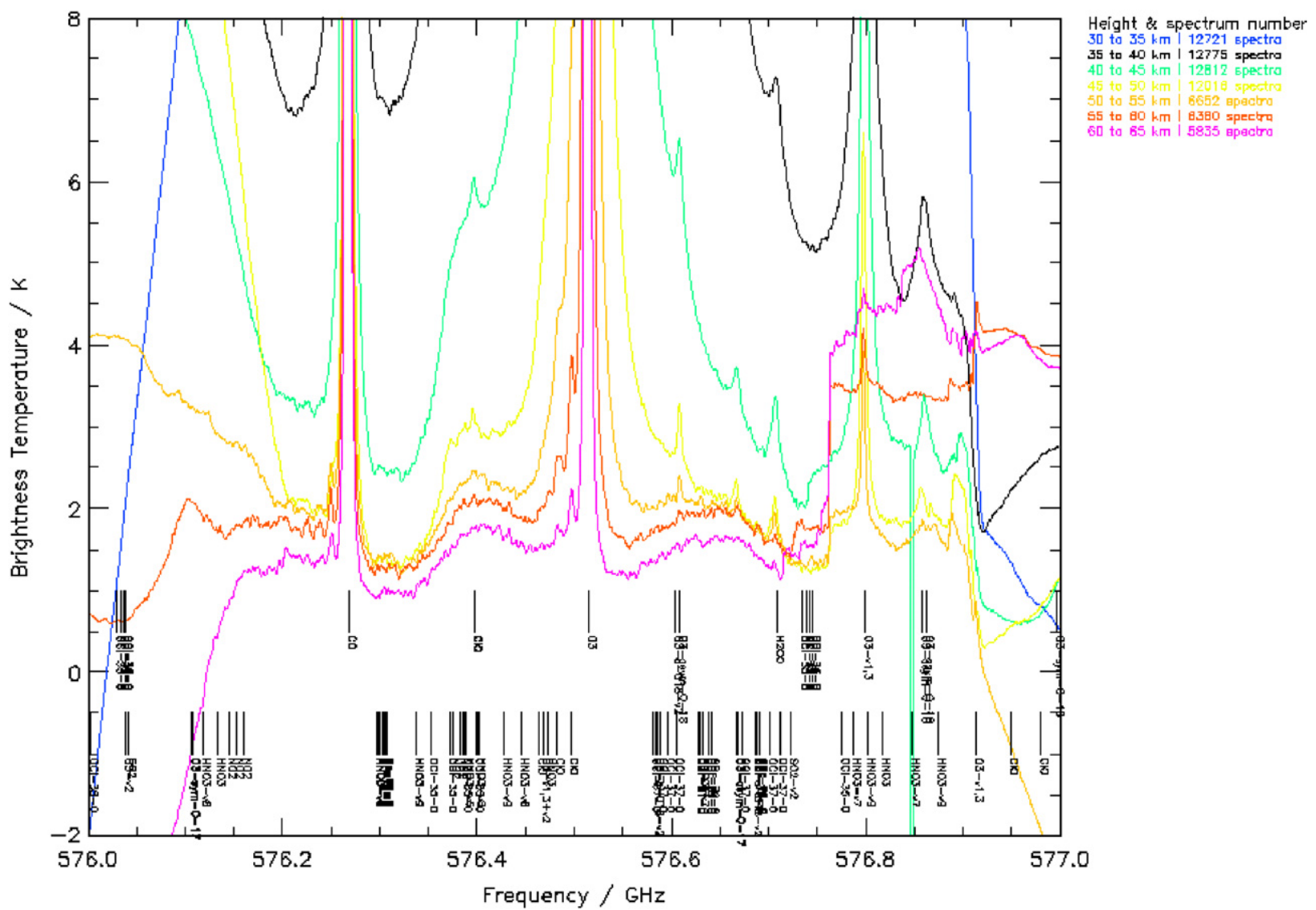

Fig. 4. Same as Fig. 2, but highlighting all the non-negligible transitions and molecules present in the 576-GHz band.

\section{REPROBUS model}

Three-dimensional simulations of the December 2002-November 2003 period have been performed with the Reprobus Chemical transport model [14,23]. The outputs from this model have been used in different studies for interpreting Odin results, mainly at high latitudes [24,25]. The updated version of the model is presented in [24].

Reprobus was integrated from 1st October 2002 to 31st December 2003. The $\mathrm{N}_{2} \mathrm{O}, \mathrm{CH}_{4}, \mathrm{H}_{2} \mathrm{O}, \mathrm{HNO}_{3}$ and $\mathrm{ClONO}_{2}$ fields were initialized from the zonally averaged measurements made by the Michelson interferometer for passive atmospheric sounding (MIPAS) instrument aboard the ENVISAT satellite on 1st October 2002. The $\mathrm{O}_{3}$ field was initialized on 1 October 2002 from the three-dimensional ECMWF $\mathrm{O}_{3}$ analysis. Other species were initialized from an October zonal mean computed from a long-term simulation of Reprobus. Temperature, winds, and ground pressure were specified from the 3-hourly ECMWF operational analysis. The model extends from the surface up to $0.1 \mathrm{hPa}$ on 42 levels, resulting in a vertical resolution of about $1.3 \mathrm{~km}$ in the lower stratosphere. The horizontal resolution is $2^{\circ}$ latitude by $2^{\circ}$ longitude.

The monthly-averaged $\mathrm{H}_{2} \mathrm{CO}$ fields as simulated by the Reprobus model from December 2002 to November 2003 are presented in Fig. 6. The distribution of $\mathrm{H}_{2} \mathrm{CO}$ shows two strong maxima in the tropical lower troposphere induced by the tropospheric climatology and in the tropical mid-stratosphere due to methane oxidation. Furthermore, there are very well marked seasonal variations in the mid-stratospheric fields with strong maxima at summer high latitudes and, conversely, minima at high winter latitudes within polar vortices. These seasonal variations are consistent with stronger illumination at summer high latitudes 
a

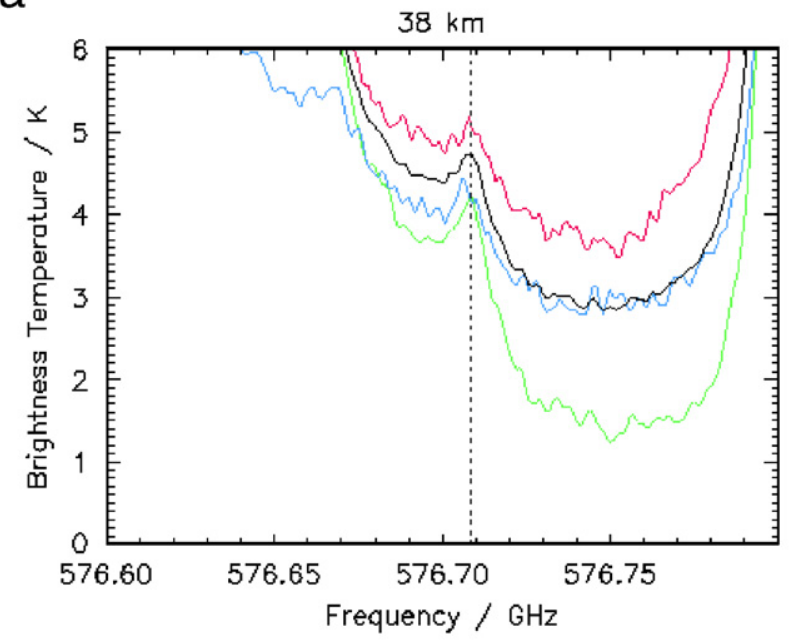

C

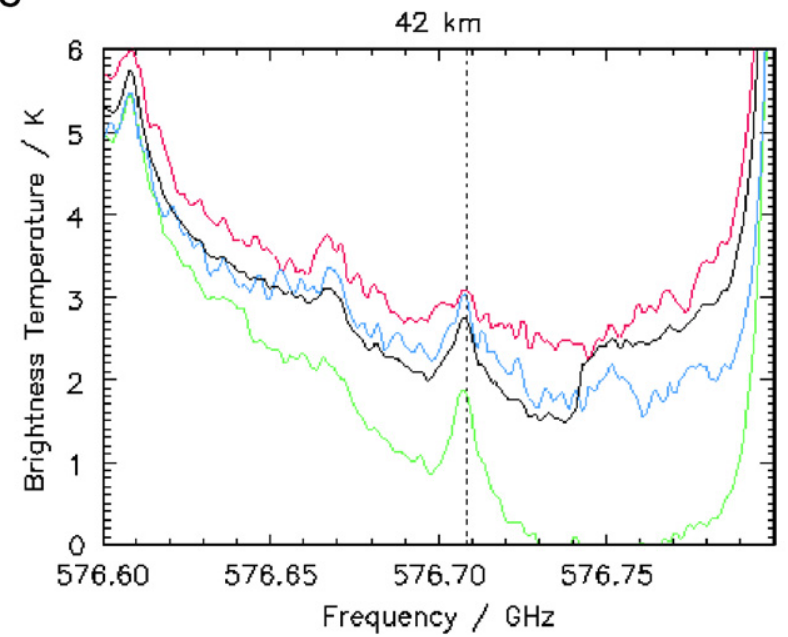

b

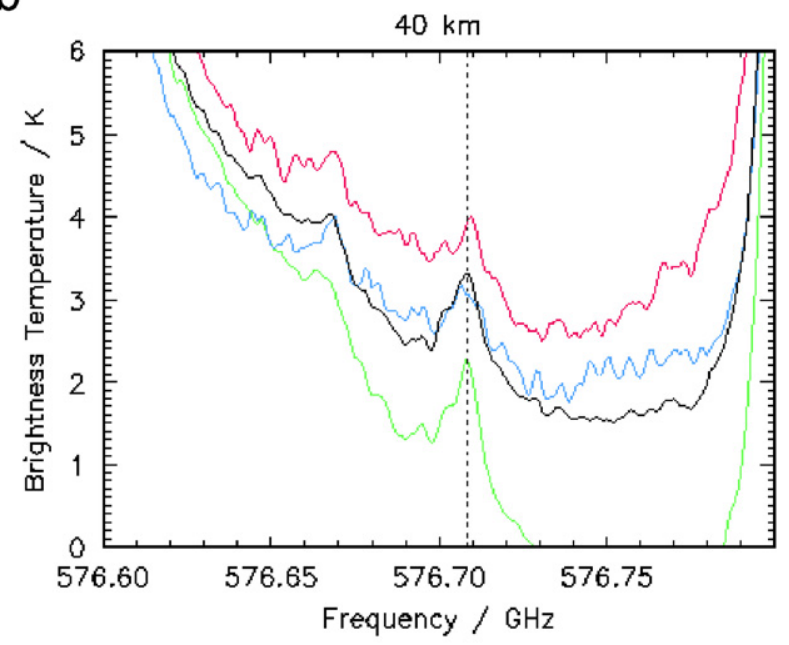

d

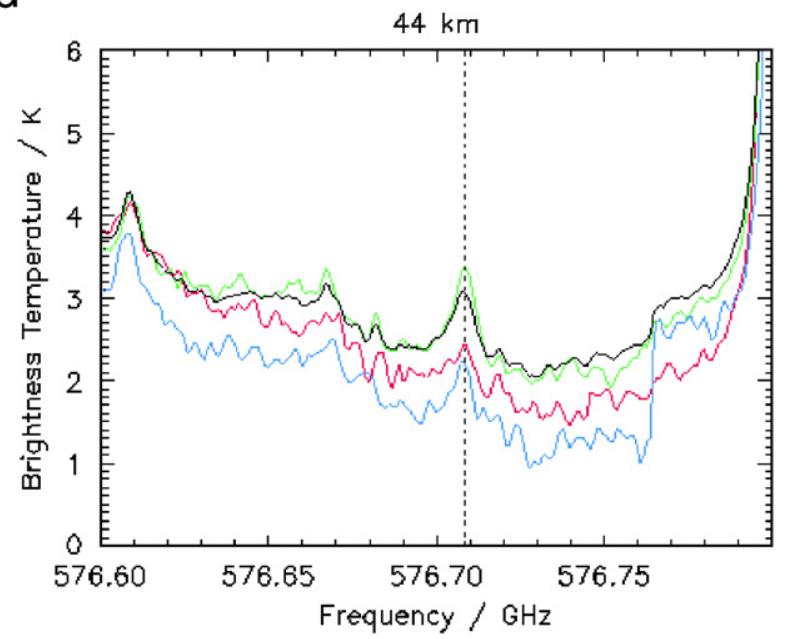

Fig. 5. Evolution of the $\mathrm{H}_{2} \mathrm{CO}$ lines when averaged over the January 2006 period within 4 vertical layers: (a) $38 \mathrm{~km}$, (b) $40 \mathrm{~km}$, (c) $42 \mathrm{~km}$, and (d) $44 \mathrm{~km}$, and within different latitude bands: mid-to-high Southern Hemisphere latitudes (SH: $\left.90^{\circ} \mathrm{S}-45^{\circ} \mathrm{S}\right)$ (red line), tropics $\left(30^{\circ} \mathrm{S}-30^{\circ} \mathrm{N}\right)$ (green line), mid-to-high Northern Hemisphere latitudes $\left(\mathrm{NH}: 45^{\circ} \mathrm{N}-90^{\circ} \mathrm{N}\right)$ (blue line), and global $\left(90^{\circ} \mathrm{S}-90^{\circ} \mathrm{N}\right)(\mathrm{black}$ line).

compared to winter latitudes producing $\mathrm{O}\left({ }^{1} \mathrm{D}\right)$ and $\mathrm{OH}$ that oxidize $\mathrm{CH}_{4}$ and, finally, produces $\mathrm{H}_{2} \mathrm{CO}$. Since the strongest illumination is located in the tropics, we naturally expect $\mathrm{H}_{2} \mathrm{CO}$ to show a tropical maximum in the stratosphere.

\section{Data analysis}

\subsection{MOLIERE}

The CTSO version V225 uses the generic Microwave Odin Line Estimation and Retrieval (MOLIERE) code [26,27] initially developed for Odin and now used in different programs from ground-based microwave instruments (e.g. $\mathrm{O}_{3}$ at $110 \mathrm{GHz}$ [28]; $\mathrm{ClO}$ at $278 \mathrm{GHz}$ [29]; $\mathrm{H}_{2} \mathrm{O}$ at $22 \mathrm{GHz}$ [Motte et al., manuscript in preparation]), to airborne instruments (e.g. $\mathrm{ClO}$ at $649 \mathrm{GHz}$ from the airborne sub-mm SIS radiometer (ASUR) [26]) and space-borne projects (e.g. $\mathrm{O}_{3}$ and $\mathrm{CO}$ around $320 \mathrm{GHz}$ with the stratosphere-troposphere exchange and climate monitor (STEAM) [30]). 

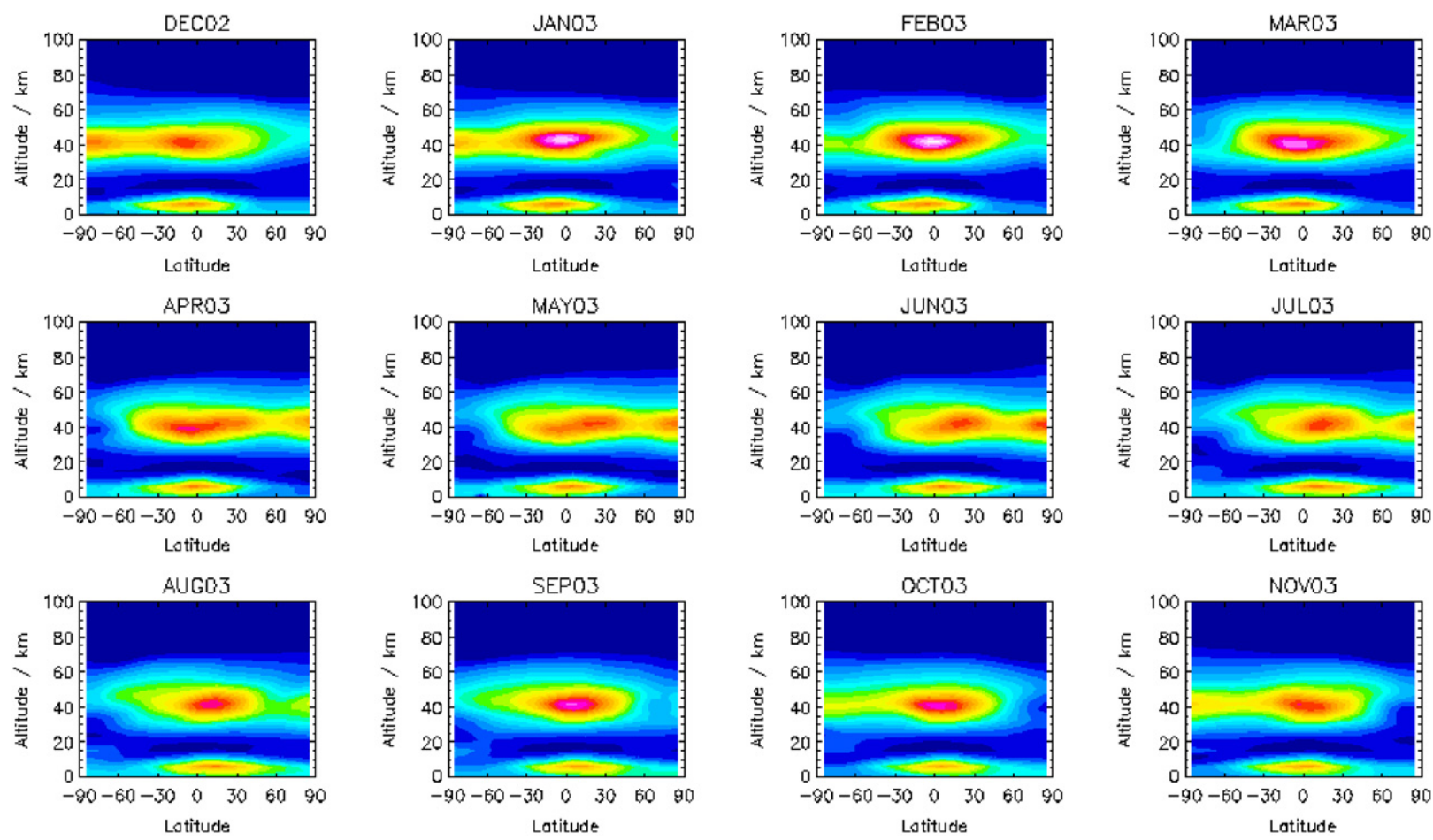

REPROBUS: $\mathrm{CH} 20$

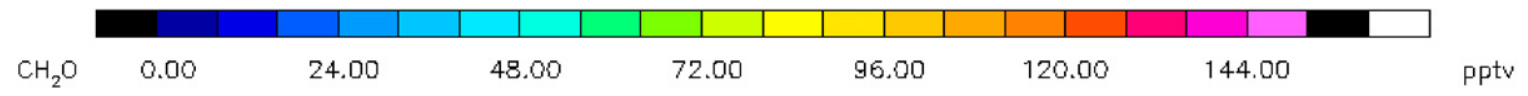

Fig. 6. Monthly averaged zonal mean $\mathrm{H}_{2} \mathrm{CO}$ fields as calculated by the three-dimensional chemical-transport model Reprobus from December 2002 to November 2003 (pptv).

The MOLIERE code is separated into a forward model and a retrieval code. The forward model includes modules for spectroscopy, radiative transfer and sensor characteristics (antenna, sideband and spectrometer). It also includes different shape of baseline undulations from linear and quadratic to sine functions. The retrieval code is based upon the optimal estimation method [31] and, coupled with the forward model, allows nonlinear retrievals according to a Newton Levenberg-Marquardt iteration scheme. A scan bias parameter can also be estimated between the measured and retrieved tangent heights, together with a spectrometer shift parameter that rescales in frequency the measured spectra for each tangent height within $1 \mathrm{MHz}$. An additional noise parameter can also be added to the random radiometric noise in order to cope with any spurious noise that cannot be fitted by an algebraic mathematical function.

Spectroscopic line parameters for the line-by-line calculations have been taken from the Verdandi database (http://www.rss.chalmers.se/gem/Research/verdandi.html), which merges frequencies, lines intensities, and lower state energies from the JPL catalog [22] with pressure broadening parameters from the HITRAN compilation [32]. Table 1 lists the spectroscopic information related to the $\mathrm{H}_{2} \mathrm{CO}$ line used in our analysis, namely the frequency of the transition, the intensity of the line at $300 \mathrm{~K}$, the lower state energy, the broadening coefficient relative to the air, the self-broadening coefficient, and their temperature dependences. The spectroscopic information relative to the other molecules is similar to the ones presented in the CO studies by [19] and [21].

The a priori information for $\mathrm{O}_{3}$ and all molecules except $\mathrm{CO}$ and $\mathrm{H}_{2} \mathrm{CO}$ is provided by the Odin climatology set up for all the studies performed so far. The a priori information for $\mathrm{CO}$ and $\mathrm{H}_{2} \mathrm{CO}$ is based upon the monthly average outputs from the REPROBUS model from the surface to $110 \mathrm{~km}$ and from December 2002 to November 2003 into latitude bins of $10^{\circ}$. Temperature, pressure, and altitude fields are provided by the 
Table 1

Spectroscopic parameters related to the $\mathrm{H}_{2} \mathrm{CO}$ line used in our analysis, namely the frequency of the transition $(\mathrm{MHz}), \log _{10}$ of the intensity of the line at $300 \mathrm{~K}\left(\mathrm{~nm}^{2} \mathrm{MHz}\right)$, the lower state energy $\left(\mathrm{cm}^{-1}\right)$, the broadening coefficient relative to the air $\left(\mathrm{MHz}\right.$ Torr $\left.{ }^{-1}\right)$, the self-broadening coefficient $\left(\mathrm{MHzTorr}^{-1}\right)$, and their temperature dependences

Spectroscopic parameters for $\mathrm{H}_{2} \mathrm{CO}$ used in MOLIERE

\begin{tabular}{llllllll}
\hline Species & $\begin{array}{l}\text { Frequency } \\
(\mathrm{MHz})\end{array}$ & $\begin{array}{l}\log _{10} \text { (intensity) } \\
\text { at } 300 \mathrm{~K} \\
\left(\mathrm{~nm}^{2} \mathrm{MHz}\right)\end{array}$ & $E_{\text {low }}\left(\mathrm{cm}^{-1}\right)$ & $\begin{array}{l}\gamma_{\text {air }}^{0} \text { at } 296 \mathrm{~K} \\
\left(\mathrm{MHzTorr}^{-1}\right)\end{array}$ & $\begin{array}{l}\gamma_{\text {self }}^{0} \text { at } 296 \mathrm{~K} \\
\left(\mathrm{MHzTorr}^{-1}\right)\end{array}$ & $n_{\text {air }}$ & $n_{\text {self }}$ \\
\hline $\mathrm{H}_{2} \mathrm{CO}$ & 576708.3150 & -1.6379 & 67.7252 & 4.22 & 4.22 & 0.5 & 0.5 \\
\hline
\end{tabular}

ECMWF. We have selected ECMWF profiles at $0^{\circ}$ longitude, and latitudes of $70^{\circ} \mathrm{S}, 0^{\circ}$ and $70^{\circ} \mathrm{N}$, for the $\mathrm{SH}$, tropics, and NH bands, respectively. In general, the ECMWF analyses are taken as close as possible to the middle of the time average interval. The assumed a priori error for the retrieved mixing ratios corresponds to $75 \%$ of the climatological a priori mixing ratios. The additional noise parameter is set to $5 \mathrm{~K}$.

\subsection{Methodology}

The methodology we have used to estimate the $\mathrm{H}_{2} \mathrm{CO}$ vertical profiles is divided in two parts. Firstly, once the averaged spectra are produced and an averaged scan is created, we retrieve the vertical profiles of $\mathrm{O}_{3}$ and $\mathrm{CO}$ using the standard setup for the $\mathrm{CO}$ band without retrieving temperature information as described in [21]. The retrieved $\mathrm{O}_{3}$ and $\mathrm{CO}$ vertical profiles are then used as a priori vertical profiles for actually estimating the distribution of $\mathrm{H}_{2} \mathrm{CO}$ from a set of spectra restricted within a micro-window of \pm 20 channels around the $\mathrm{H}_{2} \mathrm{CO}$ transition line.

The retrieval set up in this second stage is as follows. The a priori $\mathrm{H}_{2} \mathrm{CO}$ vertical profile is kept the same whatever the latitude and period considered. Indeed, we use the same philosophy as prescribed in the retrieval of the nadir-viewing measurements of pollution in the troposphere (MOPITT) instrument [33] onboard the Terra platform for which the retrievals are non-negligibly contaminated by the a priori information [34]. Consequently, any latitudinal and/or time variability in the estimated vertical profile is not caused by the variability of the a priori information. The assumed a priori error for the retrieved mixing ratios corresponds to $75 \%$ of the a priori mixing ratios. The a priori value of the spectrometer shift parameter is tuned to $+3 \mathrm{MHz}$ for each tangent height (with an error of $0.5 \mathrm{MHz}$ ) in order to converge more rapidly, namely after 2-3 iterations instead of 10 iterations if this parameter is set to 0 . A first-degree polynomial function is set up and estimated to reproduce the spectral baseline. The additional noise parameter is decreased down to $0.5 \mathrm{~K}$.

Fig. 7a, b, and c show the measured, modeled and fitted spectra at 40-km tangent height in the SH, tropics, and NH bands, respectively for the January 2006 period. The modeled spectra refer to the spectra obtained from the forward model using a priori information. The fitted spectra are calculated from the forward model based on the information estimated after $2-3$ iterations. Although the modeled spectra is $0.5-1.0 \mathrm{~K}$ apart from the measured spectra, after 2-3 iterations the estimated spectra perfectly fit the measured spectra. The associated residuals (difference between measured and fitted spectra) are shown in Fig. 7d, e, and $\mathrm{f}$, respectively. They are all within $0.2-0.3 \mathrm{~K}$, i.e. well within the additional noise parameter imposed to be $0.5 \mathrm{~K}$. In order to check the robustness of the retrievals, we have used a sine function with a period of $7 \mathrm{MHz}$, as can be suggested from the residuals, in addition to the first-degree polynomial spectral baseline. No significant changes were detected in the retrieved $\mathrm{H}_{2} \mathrm{CO}$ mixing ratios.

The vertical profiles of $\mathrm{H}_{2} \mathrm{CO}$ estimated over the three $\mathrm{SH}$, tropics, and $\mathrm{NH}$ bands are presented in Fig. 8a, $\mathrm{b}$, and c, respectively. Superimposed are presented the a priori profile which is the same for any of the latitude band, together with the a priori error. The right hand-side also shows the $\mathrm{H}_{2} \mathrm{CO}$ averaging kernels. The width at half maximum of the averaging kernels can be considered as representative of the vertical resolution of the measurements. The sum of the elements of each averaging kernel (the measurement response) is an indication of the a priori contamination upon the retrieved information. We usually flag retrievals as good when the 
a

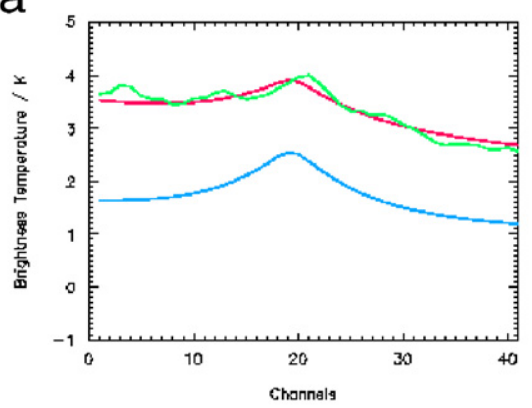

d

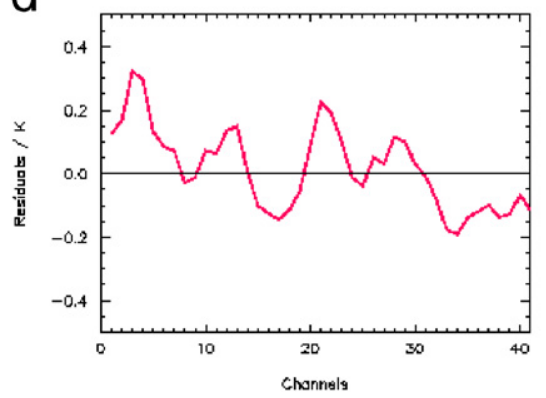

b

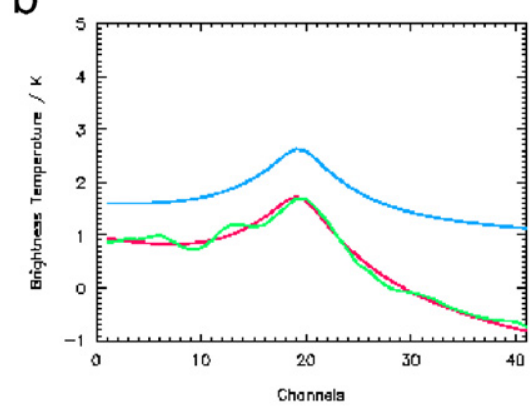

e

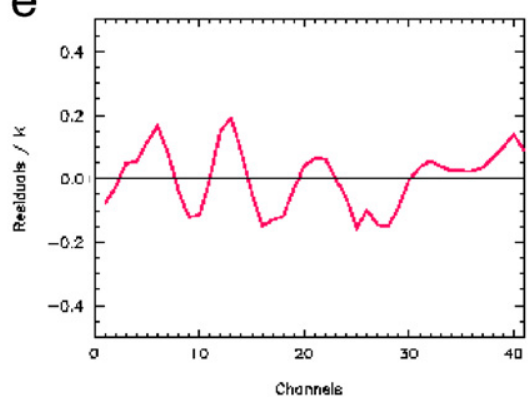

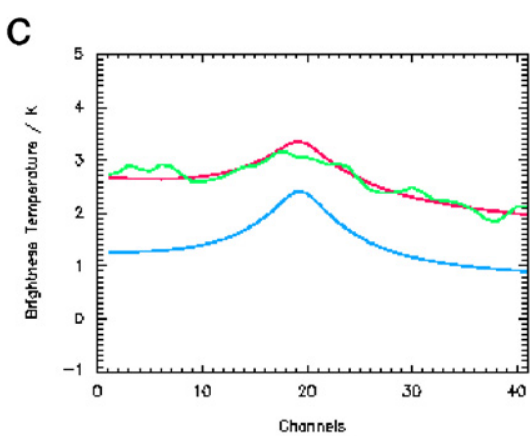

f

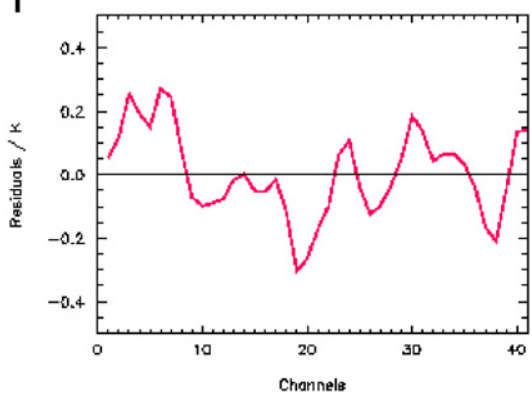

Fig. 7. Formaldehyde spectra averaged over the January 2006 period within a 2-km width layer centered at $41 \mathrm{~km}$ measured (green line), modeled (blue line) and fitted after 2 iterations (red line) (a) in the SH, (b) tropics, and (c) NH bands. Residuals (difference between measured and fitted (red line) spectra) corresponding to the (d) $\mathrm{SH}$, (e) tropics, and (f) $\mathrm{NH}$ bands.

measurement response is greater than 0.75 , meaning that the a priori information contaminates the retrieval by less than $25 \%$. In our study, the vertical domain where $\mathrm{H}_{2} \mathrm{CO}$ can be retrieved is ranging from $\sim 35 \mathrm{~km}$ up to $\sim 53 \mathrm{~km}$. The vertical resolution is ranging from $\sim 4 \mathrm{~km}$ in the middle stratosphere up to $\sim 7 \mathrm{~km}$ in the upper stratosphere. The relative error on the $\mathrm{H}_{2} \mathrm{CO}$ profile is about $30 \%$. The correlation between retrieved $\mathrm{H}_{2} \mathrm{CO}$ and the estimation of other parameters, namely scan bias, spectrometer shift and linear baseline, is very weak, less than $10 \%$.

\section{Results and discussion}

The vertical distribution of $\mathrm{H}_{2} \mathrm{CO}$ in the mid-stratosphere during the January 2006 period shows very interesting results that were expected from the intensities of the line (see Section 2.2). Indeed, the vertical distribution of $\mathrm{H}_{2} \mathrm{CO}$ in the tropics (Fig. 8b) shows a broad maximum reaching a value of $\sim 120$ pptv (part per trillion volume $=10^{-12}$ ) centered at the altitude of about $40 \mathrm{~km}$. In the $\mathrm{SH}$ and $\mathrm{NH}$ bands (Fig. 8a and c, respectively), the vertical distribution of $\mathrm{H}_{2} \mathrm{CO}$ does not exhibit such a broad maximum. In the SH band, $\mathrm{H}_{2} \mathrm{CO}$ decreases with height from $\sim 100 \mathrm{pptv}$ at $37 \mathrm{~km}$ down to $\sim 30 \mathrm{pptv}$ at $53 \mathrm{~km}$, while in the $\mathrm{NH}$, the vertical distribution of $\mathrm{H}_{2} \mathrm{CO}$ does not show lots of variability with values within $50-70 \mathrm{pptv}$.

We have then decided to use the maximum of data of good quality obtained so far with Odin/SMR in order to study the temporal and latitudinal distribution of $\mathrm{H}_{2} \mathrm{CO}$. Because of the sporadic frequency of $\mathrm{CO}$ measurements over the entire Odin mission, and of the two main failures of the system (the PLL and one of the $100-\mathrm{MHz}$ sub-band of the auto-correlator), only four periods have been actually selected. We name these four periods: January (13-31 January 2006, 7 days of measurement), February (15-16 February 2005, 1 day of measurement), March (23-24 March 2005, 1 day of measurement), and September (19-20 September 2005, 1 day of measurement). For these four periods, the methodology presented above has been applied.

To our knowledge, there are no measurements of mid-stratospheric $\mathrm{H}_{2} \mathrm{CO}$ published so far in order to validate our retrievals. We thus have used the output from Reprobus in order to check the consistency of our results. The vertical profiles of $\mathrm{H}_{2} \mathrm{CO}$ as measured by Odin/SMR and the monthly averaged Reprobus outputs 

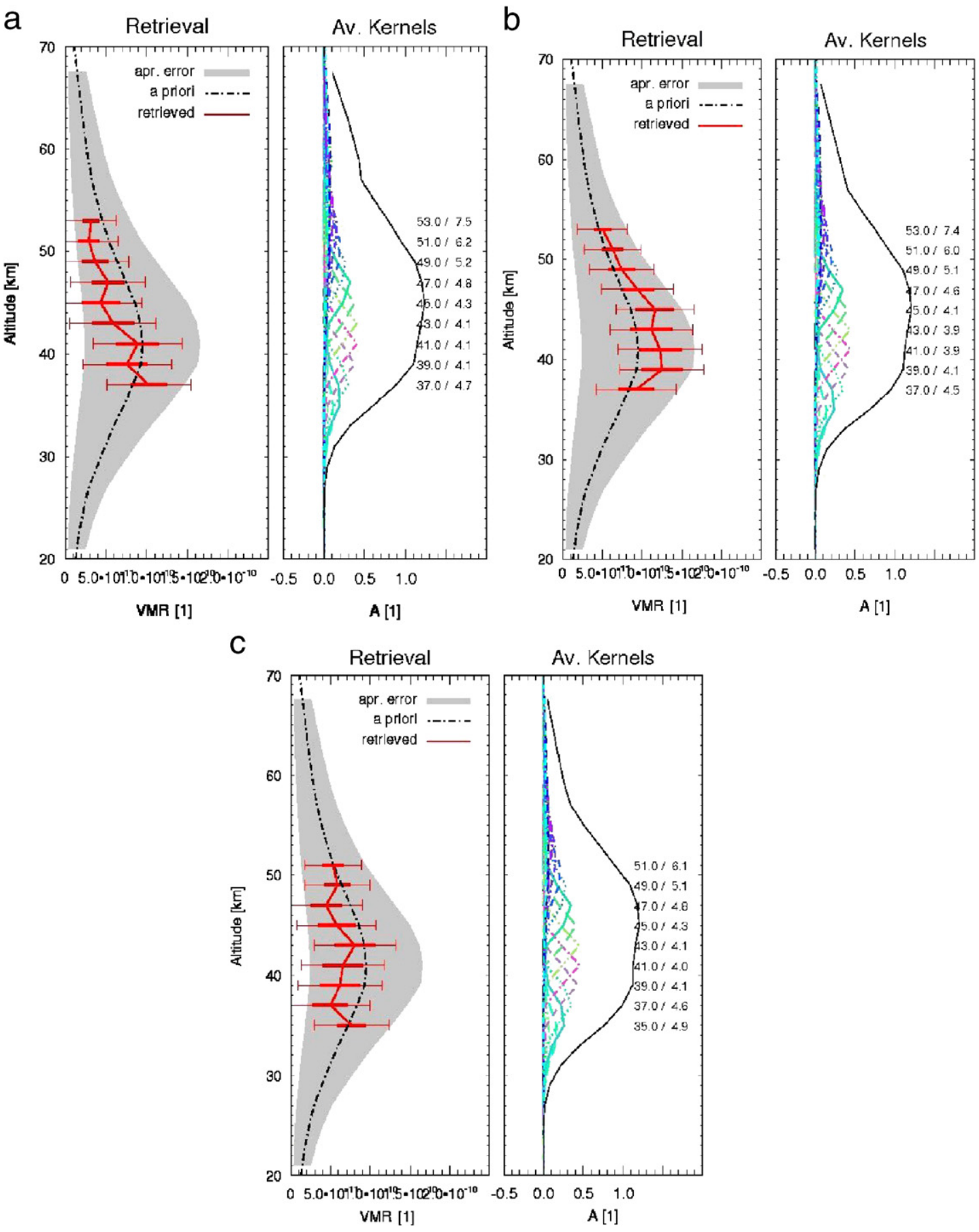

Fig. 8. (Left-hand side) Vertical profiles of $\mathrm{H}_{2} \mathrm{CO}$ estimated from the spectra averaged over the January 2006 period in (a) SH, (b) tropics, and (c) NH bands. Superimposed are presented the a priori profile (dotted line) which is the same for any of the latitude band, together with the a priori error (shaded area). The horizontal lines represent the total error (thin red line) and the measurement error (thick red line). (Right-hand side) $\mathrm{H}_{2} \mathrm{CO}$ averaging kernels. The sum of the elements of each averaging kernel (the measurement response) is an indication of the a priori contamination upon the retrieved information. The width at half maximum of the averaging kernels (representative of the vertical resolution of the measurements) together with the height where the averaging kernel is peaking are indicated on the right of each figure for altitudes where the measurement response is greater than 0.75 , i.e. the a priori contamination is less than $25 \%$. 
a

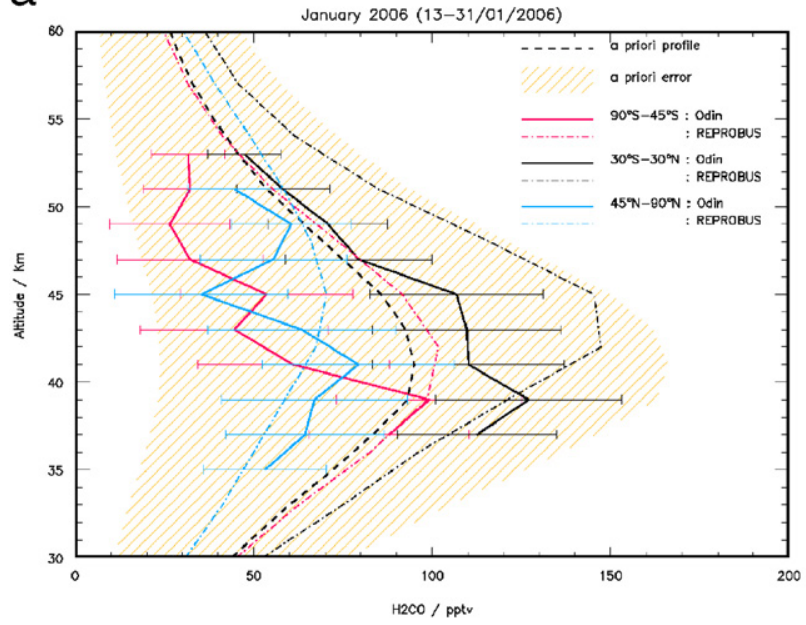

C

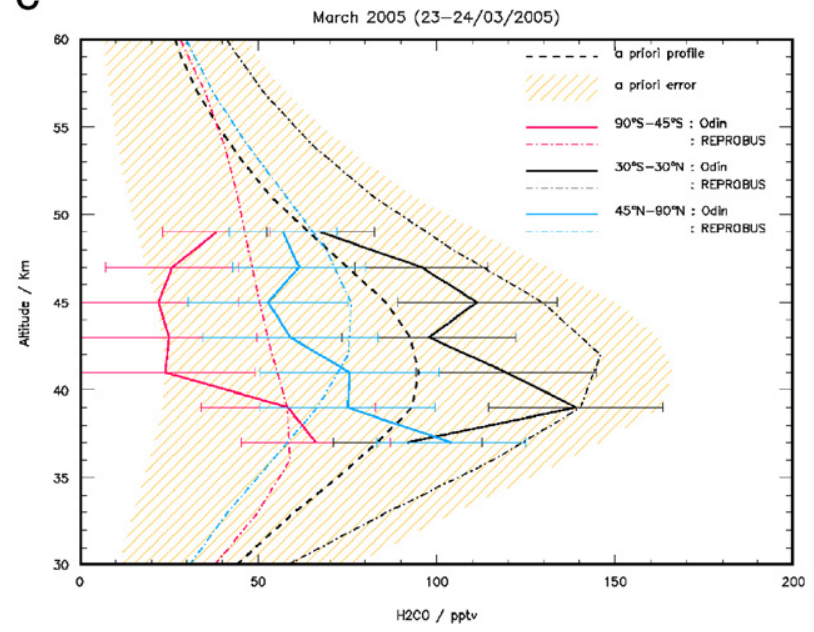

b

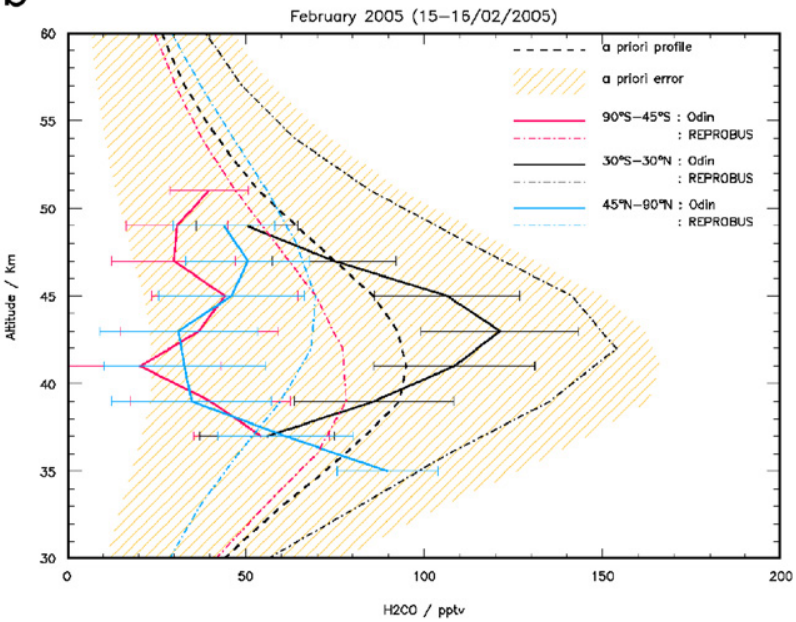

d

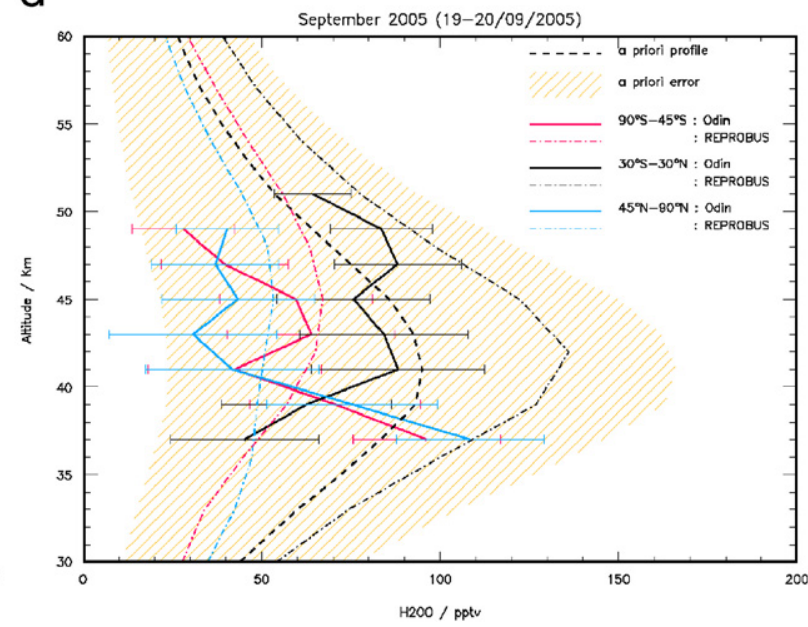

Fig. 9. Vertical profiles of $\mathrm{H}_{2} \mathrm{CO}$ as measured by Odin/SMR (coloured solid line) and the monthly averaged Reprobus outputs (coloured dashed line) corresponding to the month under consideration, together with the a priori $\mathrm{H}_{2} \mathrm{CO}$ profile (black dashed line) for the three latitude bands: SH (red lines), tropics (green lines), and NH (blue lines) for the 4 periods: (a) January 2006, (b) February 2005, (c) March 2005, and (d) September 2005, together with the a priori error (orange shaded area), and the measurement error (horizontal bars).

(see Section 3) corresponding to the month under consideration, together with the a priori $\mathrm{H}_{2} \mathrm{CO}$ profile, are presented in Fig. 9a, b, c and d for the 4 periods (January, February, March and September, respectively), and for the three bands ( $\mathrm{SH}$, tropics, and $\mathrm{NH})$. We first note that for all the periods the tropical mid-stratospheric $\mathrm{H}_{2} \mathrm{CO}$ is higher than the $\mathrm{SH}$ and $\mathrm{NH} \mathrm{H}_{2} \mathrm{CO}$. The tropical maximum is peaking around $40-43 \mathrm{~km}$ and reaches about 100-130 pptv for the periods January, February and March while it is less intense in September reaching values of 80-90 pptv. Reprobus also shows tropical $\mathrm{H}_{2} \mathrm{CO}$ maxima (120-150 pptv) more intense than $\mathrm{SH}$ and $\mathrm{NH} \mathrm{H}_{2} \mathrm{CO}(\leqslant 100 \mathrm{pptv})$. The tropical seasonality is also calculated by Reprobus with January, February and March maxima ( 150 pptv) greater than September maxima $(120-140 \mathrm{pptv})$. The modeled $\mathrm{H}_{2} \mathrm{CO}$ in the tropics is consistently more abundant than measured by Odin/SMR.

In January, the SH profile gradient is more accentuated than the gradient in the NH profile. Indeed, $\mathrm{SH}$ $\mathrm{H}_{2} \mathrm{CO}$ decreases from $100 \mathrm{pptv}$ at $37 \mathrm{~km}$ to $30 \mathrm{pptv}$ at $53 \mathrm{~km}$ while it only decreases from about $70 \mathrm{pptv}$ at $40 \mathrm{~km}$ to about $50 \mathrm{pptv}$ at around $51 \mathrm{~km}$ in the NH. This is to a lesser extent present in the modeled profiles, with maxima of $\mathrm{H}_{2} \mathrm{CO}$ more pronounced in the $\mathrm{SH}$ (100 pptv) than in the $\mathrm{NH}$ (70 pptv). In February, the $\mathrm{SH}$ and $\mathrm{NH}$ measured profiles are practically identical, decreasing with height from $60 \mathrm{pptv}$ at $37 \mathrm{~km}$ to 40 pptv at 
$49 \mathrm{~km}$. There are very little differences $(<10 \mathrm{pptv})$ between the modeled SH and NH profiles, being slightly greater than the measured profiles by about 20 pptv. In March, the measured NH profile is much greater than the measured SH profile by about 20-30 pptv. This is also observed in the modeled SH and NH profiles. In September, the $\mathrm{SH}$ and $\mathrm{NH}$ measured and simulated profiles are within $10 \mathrm{pptv}$. Finally, we must note that Reprobus $\mathrm{H}_{2} \mathrm{CO}$ mid-stratospheric amounts are generally slightly greater than Odin/SMR retrievals.

\section{Conclusions}

The sub-millimeter radiometer (SMR) instrument onboard the Odin satellite has been sounding the Earth's atmosphere since February 2001 and is still operational. In addition to the rotational transitions of target species defined prior to the launch of the mission, namely $\mathrm{O}_{3}, \mathrm{ClO}$, etc., measured in the frequency domains 486.1-503.9 and 541.0-580.4 GHz, some particular micro-windows enable the detection of weak line species. The present study focuses on the only weak $\left(8_{08} \rightarrow 7_{07}\right)$ rotational transition line of $\mathrm{H}_{2} \mathrm{CO}$ that can be measured by Odin/SMR at $576.7083150 \mathrm{GHz}$ in the band dedicated to the measurement of CO. A methodology is explained based upon the average of spectra within 2-km depth vertical layers in order to increase the signalto-noise ratio so that the $1-\mathrm{K}$ amplitude of the $\mathrm{H}_{2} \mathrm{CO}$ line is well above the $0.1-\mathrm{K}$ averaged random noise. Due to the failure of the Phase-Lock Loop and of the $100-\mathrm{MHz}$ sub-band of the auto-correlator, all the measured spectra have been frequency calibrated prior to the averaging processing. A two-step retrieval process (1) enables the estimation of $\mathrm{O}_{3}$ and $\mathrm{CO}$ from the two strong lines in this particular band, and (2) used as an $a$ priori information, helps characterizing mid-stratospheric $\mathrm{H}_{2} \mathrm{CO}$ using the scientific ground-segment developed for analyzing the Odin/SMR measurements. Vertical profiles of $\mathrm{H}_{2} \mathrm{CO}$ have been estimated for the first time from 37 to $53 \mathrm{~km}$ with a relative error of about $30 \%$ and a vertical resolution ranging from 4 to $7 \mathrm{~km}$ within three different latitude bands: mid-to-high Southern Hemisphere latitudes ( $\mathrm{SH}$ : $\left.90^{\circ} \mathrm{S}-45^{\circ} \mathrm{S}\right)$, tropics $\left(30^{\circ} \mathrm{S}-30^{\circ} \mathrm{N}\right)$, and mid-to-high Northern Hemisphere latitudes $\left(\mathrm{NH}: 45^{\circ} \mathrm{N}-90^{\circ} \mathrm{N}\right)$. These original profiles have been studied over four different periods: January 2006, February 2005, March 2005, and September 2005. During all of these periods, the tropical mid-stratospheric $\mathrm{H}_{2} \mathrm{CO}$ is more intense than the $\mathrm{SH}$ and $\mathrm{NH}$ values. Interestingly, the spring-time extra-tropical $\mathrm{H}_{2} \mathrm{CO}$ is more intense than the fall-time amounts. While no other measurements of mid-stratospheric $\mathrm{H}_{2} \mathrm{CO}$ exist, comparisons with the three-dimensional Reprobus chemical-transport model are very encouraging showing a strong tropical maximum whatever the month considered, and seasonal variability of the extra-tropical $\mathrm{H}_{2} \mathrm{CO}$. Our future program is to analyze all the measurements obtained so far containing spectroscopic information on the $\mathrm{H}_{2} \mathrm{CO}$ line in order to build climatology of mid-stratospheric $\mathrm{H}_{2} \mathrm{CO}$ and to characterize its impact upon the distribution of stratospheric ozone.

\section{Acknowledgements}

Odin is a Swedish-led satellite project funded jointly by the Swedish National Space Board (SNSB), the Canadian Space Agency (CSA), the National Technology Agency of Finland (Tekes), and the Centre National d'Etudes Spatiales (CNES). We thank many of our colleagues who have contributed to the success of the Odin mission.

\section{References}

[1] De Zafra RL, Jaramillo M, Barrett J, Emmons LK, Solomon PM, Parrish A. New observations of a large concentration of ClO in the springtime lower stratosphere over Antarctica and its implications for ozone-depleting chemistry. J Geophys Res 1989;94(D9):11,423-8.

[2] Stachnik RA, Hardy JC, Tarsala JA, Waters JW, Erickson NR. Submillimeterwave heterodyne measurements of stratospheric ClO, $\mathrm{HCl}, \mathrm{O}_{3}$, and $\mathrm{HO}_{2}$ : first results. Geophys Res Lett 1992;19(19):1931-4.

[3] de Valk JPJMM, Goede APH, de Jonge ARW, Mees J, Franke B, Crewell S, et al. Airborne heterodyne measurements of stratospheric $\mathrm{ClO}, \mathrm{HCl}, \mathrm{O}_{3}$, and $\mathrm{N}_{2} \mathrm{O}$ during SESAME 1 over northern Europe. J Geophys Res 1997;102(D1):1391-8.

[4] Waters JW, Froidevaux L, Manney GL, Read WG, Elson LS. MLS observations of lower stratospheric ClO and O3 in the 1992 southern hemisphere winter. Geophys Res Lett 1993;20(12):1219-22. 
[5] Livesey NJ, Fromm MD, Waters JW, Manney GL, Santee ML, Read WG. Enhancements in lower stratospheric $\mathrm{CH}_{3} \mathrm{CN}$ observed by the Upper Atmosphere Research Satellite Microwave Limb Sounder following boreal forest fires. J Geophys Res 2004;109:D06308.

[6] Nordh HL, von Schéele F, Frisk U, et al. The Odin orbital observatory. Astron Astrophys 2003;402(3):L21-5.

[7] Zelinger Z, Barret B, Kubat P, Ricaud P, Attié JL, Le Flochmoën E, et al. Observation of $\mathrm{HD}^{18} \mathrm{O}$, $\mathrm{CH} 3 \mathrm{OH}$ and vibrationally-excited N2O from Odin/SMR measurements. Mol Phys 2006;104(16-17):2815-20.

[8] Chance K, Palmer PI, Spurr RJD, Martin RV, Kurosu TP, Jacob DJ. Satellite observations of formaldehyde over North America from GOME. Geophys Res Lett 2000;27(21):3461-4.

[9] Notholt J, Toon GC, Rinsland CP, Pougatchev NS, Jones NB, Connor BJ, et al. Latitudinal variations of trace gas concentrations in the free troposphere measured by solar absorption spectroscopy during a ship cruise. J Geophys Res 2000;105(D1):1337-50.

[10] Paton-Walsh C, Jones NB, Wilson SR, Haverd V, Meier A, et al. Measurements of trace gas emissions from Australian forest fires and correlations with coincident measurements of aerosol optical depth. J Geophys Res 2005;110:D24305.

[11] Roller C, Fried A, Walega J, Weibring P, Tittel F. Advances in hardware, system diagnostics software, and acquisition procedures for high performance airborne tunable laser measurements of formaldehyde. Appl Phys B 2006;82:247-64.

[12] Heikes B, Snow J, Egli P, O’Sullivan D, Crawford J, Olson J, et al. Formaldehyde over the central Pacific during PEM-Tropics B. J Geophys Res 2001;106(D23):32717-32.

[13] Barbe A, Marche P, Secroun C, Jouve P. Measurements of tropospheric and stratospheric $\mathrm{H}_{2} \mathrm{CO}$ by an infrared high resolution technique. Geophys Res Lett 1979;6:463-5.

[14] Lefèvre F, Brasseur GP, Folkins I, Smith AK, Simon P. Chemistry of the 1991-1992 stratospheric winter: three-dimensional model simulations. J Geophys Res 1994;99:8195-9183.

[15] Millet DB, et al. Formaldehyde distribution over North America: implications for satellite retrievals of formaldehyde columns and isoprene emission. J Geophys Res 2006;111:D24S02.

[16] Murtagh D, Frisk U, Merino F, Ridal M, Jonsson A, Stegman J, et al. An overview of the Odin atmospheric mission. Can J Phys 2002;80:309-19.

[17] Llewellyn EJ, Lloyd ND, Degenstein DA, Gattinger RL, Petelina SV, Bourassa AE, et al. The OSIRIS instrument on the Odin spacecraft. Can J Phys 2004;82(6):411-22.

[18] Frisk U, Hagström M, Ala-Laurinaho J, et al. The Odin satellite I: radiometer design and test. Astron Astrophys 2003;402(3):L27-34.

[19] Dupuy É, Urban J, Ricaud P, Le Flochmoën É, Lautié N, Murtagh D, et al. Strato-mesospheric measurements of carbon monoxide with the Odin sub-millimetre radiometer: retrieval and first results. Geophys Res Lett 2004;31(20):L20101.

[20] Jin JJ, Semeniuk K, Jonsson AI, Beagley SR, McConnell JC, Boone CD, et al. Co-located ACE-FTS and Odin/SMR stratosphericmesospheric CO 2004 measurements and comparison with a GCM. Geophys Res Lett 2005;32:L15S03.

[21] Barret B, Ricaud P, Santee ML, Attié JL, Urban J, Le Flochmoën E, et al. Intercomparisons of trace gases profiles from the SMR and the MLS space-borne sounders. J Geophys Res 2006;111(D21):D21302.

[22] Pickett HM, Poynter RL, Cohen EA, Delitsky ML, Pearson JC, Muller HSP. Submillimeter, millimeter, and microwave spectral line catalog. JQSRT 1998;60:883-90.

[23] Lefèvre F, Figarol F, Carslaw KS, Peter T. The 1997 Arctic ozone depletion quantified from three-dimensional model simulations. Geophys Res Lett 1998;25:2425-8.

[24] Ricaud P, Lefèvre F, Berthet G, Murtagh D, Llewellyn EJ, Mégie G, et al. Polar vortex evolution during the 2002 Antarctic major warming as observed by the Odin satellite. J Geophys Res 2005;110(D5):D05302.

[25] Berthet G, Ricaud P, Lefèvre F, Le Flochmoën E, Urban J, Barret B, et al. Nighttime chlorine monoxide observations by the Odin satellite and implications for the $\mathrm{ClO} / \mathrm{Cl}_{2} \mathrm{O}_{2}$ equilibrium. Geophys Res Lett 2005;32(11):L11812.

[26] Urban J, Baron P, Lautié N, Dassas K, Schneider N, Ricaud P, et al. MOLIERE (v5): a versatile forward- and inversion model for the millimeter and sub-millimeter wavelength range. JQSRT 2003;83(3-4):529-54.

[27] Urban J, Lautié N, Le Flochmoën E, Jiménez C, Eriksson P, de La Noë J, et al. Odin/SMR limb observations of stratospheric trace gases: level 2 processing of $\mathrm{ClO}, \mathrm{N}_{2} \mathrm{O}, \mathrm{HNO}_{3}$, and $\mathrm{O}_{3}$. J Geophys Res 2005;110(D14):D14307.

[28] Schneider N, Lezeaux O, de La Noë J, Urban J, Ricaud P. Validation of ground-based observations of strato-mesospheric ozone. J Geophys Res 2003;108(D17):4540.

[29] Ricaud P, Baron P, de La Noë J. Quality assessment of ground-based microwave measurements of chlorine monoxide, ozone, and nitrogen dioxide at northern mid-latitudes. Ann Geophys 2004;22:1903-15.

[30] Ricaud P, Urban J, Murtagh D, Frisk U. STEAM: stratosphere-troposphere exchange and climate monitor. Technical Report, Observatoire de Bordeaux, France, 2002.

[31] Rodgers CD. Inverse methods for atmospheric sounding: theory and practice, 1st ed. River Edge, NJ: World Scientific; 2000.

[32] Rothman L, et al. The HITRAN Molecular Spectroscopic Database: edition of 2000 including updates through 2001. JQSRT 2003;82:5-44.

[33] Drummond JR, Mand GS. The measurements of pollution in the troposphere (MOPITT) instrument: overall performance and calibration requirements. J Atmos Ocean Technol 1996;13:314-20.

[34] Emmons LK, et al. Validation of MOPITT CO retrievals with aircraft in situ profiles. J Geophys Res 2004;109. 